\title{
International Unit
}

National Cancer Institute

\section{Source}

National Cancer Institute. International Unit. NCI Thesaurus. Code C48579.

The unitage assigned by the WHO to International Biological Standards - substances, classed as biological according to the criteria provided by WHO Expert Committee on Biological Standardization (e.g. hormones, enzymes, and vaccines), to enable the results of biological and immunological assay procedures to be expressed in the same way throug hout the world. The definition of an international unit is generally arbitrary and technical, and has to be officially approved by the International Conference for Unification of Formulae. 